\title{
A Review of Models Suitable for Quantifying the Benefits of Power Connectivity in China's Belt and Road Region
}

\author{
Zhiye Gao', Xin Gu' ${ }^{2}$, Wenjing Qin'², Baoming Huang ${ }^{2}$ \\ 1 State Grid Suzhou Power Supply Company, ${ }^{2}$ School of Economics \& Management, Southeast University, China \\ Keywords: energy connectivity, energy model, Belt and Road Energy Partnership \\ https://doi.org/10.46557/001c.28916
}

\section{Energy RESEARCH LETTERS}

Vol. 3, Issue 1, 2022

\begin{abstract}
This note reviews academic research models and reports the selection of an appropriate model that can quantify the benefits of regional power connectivity in the region of China's Belt and Road Energy Partnership. A top-down macro model is more suitable for assessing the influence of power connectivity. In contract, a bottom-up model reflecting technical characteristics is recommended for measuring the impact of national investment in power facilities on energy structure transformation.
\end{abstract}

\section{Introduction}

Energy cooperation is one of the most significant aspects of China's Belt and Road Initiative, as demonstrated by the establishment of the Belt and Road Energy Partnership (BREP). Electricity demand is growing rapidly in the region of the BREP, and its growth will continue in the future, implying a need for rapid expansion of the electricity supply (Timilsina \& Toman, 2016). However, the region has experienced high energy inequality (Hafeez et al., 2019). This energy inequality not only will continue to adversely affect economic and social development, but also will negatively affect the environment and, thus, sustainable development.

The BREP focuses on energy transformation and green development. Several studies have explored the impact of power energy interconnection in the region. The China Pakistan Economic Corridor, a mutually beneficial and win-win pilot project between China and Pakistan, has led to huge projects for the generation of electricity to solve the severe electricity shortage. Seven power generation projects are coal-based power plants, which cause greenhouse gas emissions; advanced technology is thus advised to control these emissions (Solangi et al., 2018). China-Myanmar energy projects have achieved positive results, and the two sides are committed to renewable energy cooperation. Both sides are technologically and economically complementary to each other in the transition toward a clean, economic, and reliable energy system (Yang et al., 2021). However, analytical models are lacking in renewable energy cooperation regarding multilateral energy interconnections in the context of the BREP. Besides, Bashir et al. (2020) note that countries with lower regulatory constraints or a smaller institutional distance are more appealing to foreign investment. However, measurement of the extent to which investment in power resources has contributed to the transition to green energy is still an unavoidable problem.

A total of 30 countries are involved in the BREP, each economy with a different level of development. To support power system connectivity and attract investments to promote the energy transition, we need a suitable model to estimate the potential benefits of regional power system connectivity. A significant amount of theoretical work has been conducted to confirm the potential benefits of regional power system connectivity. Studies target different regions and use various modeling tools to quantify the benefits. To provide model assessments in the future, a better understanding of how these benefits have been or could be quantified is necessary (Van Beeck, 2000). Therefore, this note aims to select an appropriate analytical model to quantify the benefits of power interconnection in this region.

\section{Methodology}

This note reviews the models in academic research and reports that quantify the benefits of regional power connectivity. Since it is difficult for bilateral connectivity to reflect regional characteristics, only models covering more than three countries are included. In addition, considering the diversity of energy cooperation benefits, this note only analyzes models whose output involves at least two of the aspects of the economy, society, resources, and the environment. Based on Van Beeck's (2000) division of energy models, this note analyzes the main characteristics of these models, including their geographical coverage, analytical approach, underlying methodology, and time horizon. Then, the models are matched in terms of their need to evaluate the benefits of power connectivity in countries along the Belt and Road region. The implications of the 
Table 1. Characteristics of model

\begin{tabular}{|c|c|c|c|c|c|c|c|}
\hline & Model Name & Reference & $\begin{array}{l}\text { Geographical } \\
\text { Coverage }\end{array}$ & $\begin{array}{l}\text { Analytical } \\
\text { Approach }\end{array}$ & $\begin{array}{l}\text { The } \\
\text { Underlying } \\
\text { Methodology }\end{array}$ & $\begin{array}{l}\text { Time } \\
\text { Horizon }\end{array}$ & $\begin{array}{l}\text { Output } \\
\text { Category }\end{array}$ \\
\hline 1 & $\begin{array}{l}\text { Multi-country } \\
\text { Multi-sector } \\
\text { General } \\
\text { Equilibrium } \\
\text { Model }\end{array}$ & $\begin{array}{l}\text { (Abrell \& } \\
\text { Rausch, 2016) }\end{array}$ & Europe & Top-down & $\begin{array}{l}\text { General } \\
\text { equilibrium }\end{array}$ & $\begin{array}{l}\text { Single time, } \\
\text { yearly } \\
\text { average }\end{array}$ & $\begin{array}{l}\text { Economic, } \\
\text { Environment }\end{array}$ \\
\hline 2 & $\begin{array}{l}\text { Economic } \\
\text { Dispatch Model }\end{array}$ & $\begin{array}{l}\text { (Adeoye \& } \\
\text { Spataru, 2020) }\end{array}$ & West Africa & $\begin{array}{l}\text { Bottom- } \\
\text { up }\end{array}$ & $\begin{array}{l}\text { Simulation, } \\
\text { Optimization }\end{array}$ & $\begin{array}{l}\text { Short, } \\
\text { Medium, } \\
\text { and longer } \\
\text { terms for } \\
2030\end{array}$ & $\begin{array}{l}\text { Economic, } \\
\text { Environment, } \\
\text { Resource }\end{array}$ \\
\hline 3 & MENA Model & $\begin{array}{l}\text { (Aghahosseini } \\
\text { et al., 2016) }\end{array}$ & $\begin{array}{l}\text { Middle East } \\
\text { and North } \\
\text { Africa }\end{array}$ & $\begin{array}{l}\text { Bottom- } \\
\text { up }\end{array}$ & Optimization & Annual & $\begin{array}{l}\text { Economic, } \\
\text { Resource }\end{array}$ \\
\hline 4 & $\begin{array}{l}\text { NATGRID } \\
\text { Model }\end{array}$ & $\begin{array}{l}\text { (Chattopadhyay, } \\
\text { 2013) }\end{array}$ & $\begin{array}{l}\text { India, } \\
\text { Bhutan, } \\
\text { Nepal, Sri } \\
\text { Lanka }\end{array}$ & $\begin{array}{l}\text { Bottom- } \\
\text { up }\end{array}$ & Optimization & $\begin{array}{l}\text { Long term, } \\
\text { Single year } \\
\text { scenario } \\
\text { comparison }\end{array}$ & $\begin{array}{l}\text { Economic, } \\
\text { Environment }\end{array}$ \\
\hline 5 & $\begin{array}{l}\text { Regional } \\
\text { Energy } \\
\text { Interconnection } \\
\text { Model }\end{array}$ & $\begin{array}{l}\text { (Jiang et al., } \\
\text { 2019) }\end{array}$ & ASEAN 10 & Top-down & Simulation & Year 2050 & $\begin{array}{l}\text { Economic, } \\
\text { Environment, } \\
\text { Social, } \\
\text { Resource }\end{array}$ \\
\hline 6 & $\begin{array}{l}\text { Multi-region } \\
\text { Power System } \\
\text { Model }\end{array}$ & $\begin{array}{l}\text { (Otsuki et al., } \\
\text { 2016) }\end{array}$ & $\begin{array}{l}\text { China, Japan, } \\
\text { Korea, Russia }\end{array}$ & $\begin{array}{l}\text { Bottom- } \\
\text { up }\end{array}$ & Optimization & $\begin{array}{l}\text { Minimize a } \\
\text { single-year } \\
\text { overall } \\
\text { system } \\
\text { cost }\end{array}$ & $\begin{array}{l}\text { Economic, } \\
\text { Environment }\end{array}$ \\
\hline 7 & $\begin{array}{l}\text { Day-ahead } \\
\text { Market Model } \\
\text { \& Intraday } \\
\text { Market Model }\end{array}$ & $\begin{array}{l}\text { (Purvins et al., } \\
\text { 2020) }\end{array}$ & $\begin{array}{l}\text { Europe and } \\
\text { Central Asia }\end{array}$ & Top-down & Optimization & $\begin{array}{l}\text { Medium, } \\
\text { day-ahead } \\
\text { for the } \\
\text { entire } \\
2040\end{array}$ & $\begin{array}{l}\text { Economic, } \\
\text { Environment }\end{array}$ \\
\hline 8 & $\begin{array}{l}\text { Inter-temporal } \\
\text { or Dynamic } \\
\text { Optimization } \\
\text { Model }\end{array}$ & $\begin{array}{l}\text { (Timilsina \& } \\
\text { Toman, 2016) }\end{array}$ & South Asia & $\begin{array}{l}\text { Bottom- } \\
\text { up }\end{array}$ & Optimization & $\begin{array}{l}\text { Long-term, } \\
\text { 2015-2040 }\end{array}$ & $\begin{array}{l}\text { Economic, } \\
\text { Environment, } \\
\text { Resource }\end{array}$ \\
\hline 9 & $\begin{array}{l}\text { Europe and } \\
\text { China Model }\end{array}$ & $\begin{array}{l}\text { (Wu \& Zhang, } \\
\text { 2018) }\end{array}$ & $\begin{array}{l}\text { Europe and } \\
\text { China }\end{array}$ & $\begin{array}{l}\text { Bottom- } \\
\text { up }\end{array}$ & Optimization & Seasonal & $\begin{array}{l}\text { Economic, } \\
\text { Resource }\end{array}$ \\
\hline
\end{tabular}

model characteristics are explained below.

Geographical coverage refers to the area covered by the model, which reflects the level of the model's analysis. Geographical coverage usually affects the model structure and data usage. Models that focus on regional and country levels typically require aggregated data, whereas local and project models use disaggregated data.

The analytical approach can be classified as either topdown or bottom-up. The bottom-up model mainly describes the technology by using technology-related data, to reflect the potential of the technology in engineering research. The top-down model is effectively an economic model that can be used to forecast revenue, using aggregated data but not including the details of energy technologies.

The underlying methodology includes the economic equilibrium, optimization, and simulations. The economic equilibrium considers energy as one sector of the overall economy and analyzes its linkages with other sectors. Optimization obtains the optimal solutions of related problems through input constraint variables. Simulations are based on the system's logic to reproduce the actual situation.

The time horizon is either short, medium, or long term. The single-year model is set in a current or future year, embedding considerable temporal and technical details. It assumes no change in the capital structure and focuses on the operation of the system. On the other hand, a long-range model has a long timeframe and analyzes the evolution of the system's structure. It is used to study issues such as energy system transformation.

This note also analyzes the input and output categories of the model. The different output results are an important basis for the model selection of decision makers.

\section{Results}

This note analyzes nine models, which cover parts of the Belt and Road Initiative, mainly including countries in Asia, Europe, and Africa. The analysis results the model are shown in Table 1. The key inputs of the model are not shown in the table. 
Six models (2 to $4,6,8$, and 9) are analyzed in a bottomup approach, encompassing many characteristics of the technologies involved, including energy demand, renewable energy generation, energy storage, and energy transportation. Seven models (2 to 4 and 6 to 9) adopted an optimization whose analytical results are directly determined by the inputs. In addition, as a result of the various goals set, each model had a different time horizon. In terms of output, each model reports various economic indicators, including costs and trade. Most models (1, 2, and 4 to 8 ) report environmental indicators that are mainly reductions in emissions. Some models (2, 3, 5, 8, and 9) report resource indicators, such as energy capacity. However, only Model 5 reports the social impact of power connectivity, including employment and access to energy.

According to the above analysis, the evaluation of the benefits of power connectivity in the BREP should include the following aspects. First, the model should be capable of measuring the economic and environmental benefits brought about by power connectivity to the cooperative countries. Second, the model should be able to evaluate whether power connectivity can improve people's livelihood. Third, the model should measure the impact of national investment in power facilities on energy structure transformation. The first point can be achieved through a general model. The second point requires a top-down model to assess the social benefits of connectivity. The third point requires a bottom-up model to assess the impact of investment-induced technological progress on economic indicators.

In terms of model construction, to assess the economic benefits of technological change, Model 4 uses unit-level details to examine changes in generating capacity, distinct from the peak generating capacity generator assumptions of most models. The key inputs to Model 4 include additional hydropower output, avoided fuel costs, the cost of operating reserves, the marginal costs of generation, the expected unserved energy level, grid reinforcement costs, and coal capacity. Outputs include economization (fuel cost savings, potential reduction in unserved energy, the facilitation of power trading) and environmental indicators (e.g., in terms of $\mathrm{CO} 2$ reduction). The model is based on a single linear programming model that is easy to operate and can be used to analyze cross-border power connectivity in other regions.

To evaluate social benefits, Model 5 adopts a top-down analytical approach to reflect the relation between the power system and other economic sectors. It evaluates connectivity-driven employment through input indicators related to the population and the economy. The operation process of this model is also transparent, and the data can be directly replaced for use.

\section{Recommendations}

We suggest the following, based on the analysis above. Since the redevelopment of models requires significant time and financial resources, we recommend that countries within the BREP improve upon existing mature models to quantify the benefits of regional power connectivity. Because top-down models are more suitable for predictive applications, a top-down macro model can be used to study the social impact of interconnection and to evaluate whether power connectivity can improve people's livelihood. Simultaneously, to measure the impact of national investment in power facilities on energy structure transformation, a bottom-up model reflecting technical characteristics can be used for the analysis. Therefore, the analysis of the benefits of power connectivity in the Belt and Road region should not be limited to one model. We suggest that analysts select models appropriate to the research needs of each economy.

The limitations of this note are mentioned to spur further research. This note did not consider the operating costs of the model or the availability of data. In addition, a consideration of institutional factors in analyzing the benefits of power connection is beyond the scope of this note.

\section{Acknowledgement}

This work was supported by the National Natural Science Foundation of China [71873029]; Statistical Analysis Project of State Grid Corporation of China in Suzhou [ZXGS-2020-SZ-A-03-130]; Jiangsu Social Science Foundation [18JD008]. 


\section{REFERENCES}

Abrell, J., \& Rausch, S. (2016). Cross-country electricity trade, renewable energy and european transmission infrastructure policy. Journal of Environmental Economics \& Management, 79(sep.), 87-113. https://d oi.org/10.1016/j.jeem.2016.04.001

Adeoye, O., \& Spataru, C. (2020). Quantifying the integration of renewable energy sources in west africa's interconnected electricity network. Renewable and Sustainable Energy Reviews, 120, 109647. https://d oi.org/10.1016/j.rser.2019.109647

Aghahosseini, A., Bogdanov, D., \& Breyer, C. (2016). The MENA Super Grid towards 100\% Renewable Energy Power Supply by 2030. 11th International Energy Conference.

Bashir, M. F., Benjiang, M. A., Shahzad, L., Liu, B., \& Ruan, Q. (2020). China's quest for economic dominance and energy consumption: can asian economies provide natural resources for the success of one belt one road? Managerial and Decision Economics.

Chattopadhyay, D. (2013). Cross-border power trading in South Asia: Modelling analysis to assess economic benefits. IEEE, 1-5. https://doi.org/10.1109/pesmg.20 $\underline{13.6672071}$

Hafeez, M., Yuan, C., Khelfaoui, I., Sultan Musaad O, A., Akbar, M. W., \& Jie, L. (2019). Evaluating the energy consumption inequalities in the one belt and one road region: implications for the environment. Energies, 12(7), 1358. https://doi.org/10.3390/en12071 $\underline{358}$

Jiang, H., Gao, Y., Jun, L. I., Gao, Y., Pengfei, X. U., ... Zhang, Y. (2019). The comprehensive benefit analysis of regional energy interconnection based on system dynamics method. Journal of Global Energy Interconnection.
Otsuki, T., Mohd Isa, A. B., \& Samuelson, R. D. (2016). Electric power grid interconnections in Northeast Asia: A quantitative analysis of opportunities and challenges. Energy Policy, 89, 311-329. https://doi.or $\mathrm{g} / 10.1016 / \mathrm{j}$. enpol.2015.11.021

Purvins, A., Gerbelova, H., Sereno, L., \& Minnebo, P. (2020). Social welfare impact from enhanced transasian electricity trade. Energy.

Solangi, H., Gilal, F. G., \& Tunio, M. Z. (2018). One belt one road initiative: The origin, current status, and challenges of china-pakistan economic corridor. International Journal of Technology, Policy and Management, 18(4), 313-335. https://doi.org/10.1504/ ijtpm.2018.096180

Timilsina, G. R., \& Toman, M. (2016). Potential gains from expanding regional electricity trade in south asia. Energy Economics, 60(nov.), 6-14. https://doi.or $\mathrm{g} / 10.1016 / \mathrm{j}$.eneco.2016.08.023

Van Beeck, N. (2000). Classification of energy models. Tilburg University, Faculty of Economics and Business Administration.

Wu, C., \& Zhang, X. P. (2018). Economic analysis of energy interconnection between europe and china with $100 \%$ renewable energy generation. Global Energy Interconnection, 1(05), 6-14.

Yang, B., Swe, T., Chen, Y., Zeng, C., Shu, H., Li, X., Yu, T., Zhang, X., \& Sun, L. (2021). Energy cooperation between Myanmar and China under One Belt One Road: Current state, challenges and perspectives. Energy, 215, 119130. https://doi.org/10.1016/j.energ у.2020.119130 